\title{
Integration of Zachman Framework and TOGAF ADM on Academic Information Systems Modeling
} Integrasi Zachman Framework dan TOGAF ADM pada Pemodelan Sistem Informasi Akademik

Received:

14 August 2020

Accepted:

28 December 2020

Published:

1 February 2021

\author{
1*Abdul Fadlil, ${ }^{2}$ Imam Riadi, ${ }^{3}$ Azhar Basir \\ ${ }^{1}$ Program Studi Teknik Elektro, Universitas Ahmad Dahlan \\ ${ }^{2}$ Program Studi Sistem Informasi, Universitas Ahmad Dahlan \\ ${ }^{3}$ Program Studi Teknik Informatika, Universitas Ahmad Dahlan \\ ${ }_{1,2,3}^{3}$ Yogyakarta, Indonesia \\ E-mail:1fadlil@mti.uad.ac.id, ${ }^{2}$ imam.riadi@is.uad.ac.id \\ ${ }^{3}$ azhar1708048030@webmail.uad.ac.id
}

*Corresponding Author

\begin{abstract}
Zachman Framework (ZF) and The Open Group Architecture Framework (TOGAF) are Architecture Frameworks often used in Architecture Enterprise's implementation. Each side of the two architecture Frameworks has advantages and disadvantages. Sekolah Tinggi Manajemen Informatika dan Komputer Muhammadiyah Paguyangan Brebes (STMIK MPB) is a new university established on April 28, 2017; STMIK MPB as a new university has no plans in building an information system. The research will select the parts that exist in the ZF and TOGAF methodologies. The two methods will be combined and compiled to be applied to the Academic Information System modeling or blended methods. These research results are architectural blueprints that can be used as a reference in the development of academic information systems.
\end{abstract}

Keyword-Zachman Framework, TOGAF, ADM, Architecture, Enterprise

\begin{abstract}
Abstrak-Zachman framework $(Z F)$ dan The Open Group Architecture Framework (TOGAF) merupakan Architecture Framework yang sering digunakan dalam penerapan Architecure Enterprise, masing-masing sisi dari kedua architecture Framework tersebut memiliki kelebihan dan kekurangan. Sekolah Tinggi Manajemen Informatika dan Komputer Muhammadiyah Paguyangan Brebes (STMIK MPB) merupakan perguruan tinggi baru yang berdiri pada 28 april 2017, dan STMIK MPB sebagai perguruan tinggi baru belum memiliki perencanaan dalam membangun sistem informasi. Penelitian ini akan memilih bagian-bagian yang ada pada metodologi ZF dan TOGAF, kedua metode tersebut akan digabungkan dan disusun untuk diterapkan pada pemodelan Sistem Informasi Akademik atau bisa disebut blended methodology. Hasil dari penelitian ini berupa blueprint Arsitektur yang dapat digunakan sebagai acuan dalam pembangunan sistem informasi akademik.
\end{abstract}

Kata Kunci-Zachman Framework, TOGAF, ADM, Architecture, Enterprise 


\section{INTRODUCTION}

The increasing need for business functions is one factor that encourages organizations to take advantage of information systems [1]. Today, many organizations, enterprises, and industries that implement information systems without planning to pay attention to momentary needs, the impact of all that information systems that are implemented are not running well, and there is overlap between systems that are not integrated.[2]. Such information system conditions cause the information system to not meet the organization's needs from the highest level to the lowest organizational needs, namely operational needs[3]. Today's use of information systems is part of strategic investment for organizations, enterprises, and industries [4].

Some of the frameworks that are often used today in government, organizations, and industry are The Open Group Architecture Framework (TOGAF), Federal Enterprise Architecture Framework (FEAF), Enterprise Architecture Planning (EAP), The Department of Defense Architectural Framework (DoDAF), and Zachman. Framework[5]. According to Wartika [6], The point of view of some of these methodologies has in common, namely :

1. Business Architecture

Business plan development, application utilization, technology, and implementation require a Business Architecture, which is needed as a foundation for other enterprise architecture components.

2. Data/Information Architecture

An application system needs to manage data entities or manage information shows from the data/information architecture. It is an essential capital in supporting the business.

\section{Application Architecture}

Application architecture is deemed necessary to define what applications are needed to manage data and business support.

\section{Technology Architecture}

The technology architecture works to determine the application's technology platform, including hardware and software in managing data and business support.

Universities must own a reliable information system. Information systems are used to manage and improve the quality of academic programs and services [7]. Higher education must have an information system that can collect data, process data, analyze data, store data, retrieve data, and report data. It can be used as a means of communicating with interested parties.[8]. Muhammadiyah School of Informatics and Computer Management Paguyangan Brebes (STMIK MPB) is a new college. As a recent college, STMIKMPB has not fully used information systems to manage the administrative implementation process so that the services provided are not 
INTENSIF, Vol.5 No.1 February 2021

ISSN: 2580-409X (Print) / 2549-6824 (Online)

DOI: https://doi.org/10.29407/intensif.v5i1.14678

optimal. To optimize services, STMIK MPB is developing an information system. Building and developing information systems will be more comfortable if you follow a framework of thought with the term Enterprise Architecture (EA) framework[9]. In this case, it will be discussed how to integrate the Zachman Framework with TOGAF ADM in the STMIK MPB Academic Information System modeling.

According to Rully Pramudita[10], the perspective/layer from several developer points of view has not been seen in TOGAF ADM as in Table 1.

Table 1. COMPARISON OF THE BOTH EA FRAMEWORK

\begin{tabular}{lcc}
\hline \multicolumn{1}{c}{ EA components } & Zachman Framework & TOGAF ADM \\
\hline Early Initiation & Not clearly stated & $\sqrt{ }$ \\
\hline Vision Architecture & Not clearly stated & $\sqrt{ }$ \\
\hline Business architecture & $\sqrt{ }$ & $\sqrt{ }$ \\
\hline Information Systems Architecture & $\sqrt{ }$ & $\sqrt{ }$ \\
\hline Technology Architecture & $\sqrt{ }$ & $\sqrt{ }$ \\
\hline Opportunities and Solutions & $\mathrm{x}$ & $\sqrt{ }$ \\
\hline Migration Planning & $\mathrm{x}$ & $\sqrt{ }$ \\
\hline Governance Implementation & $\mathrm{x}$ & $\sqrt{ }$ \\
\hline Change Management Architecture & $\mathrm{x}$ & $\mathrm{x}$ \\
\hline perspective /Layers & $\sqrt{ }$ & $\sqrt{ }$ \\
\hline Knowledge Base & $\mathrm{x}$ & $\sqrt{ }$ \\
\hline EA development methodology & $\mathrm{x}$ & \\
\hline
\end{tabular}

Each phase in the TOGAF ADM is related to the current perspectives in the Zachman Framework. Table 2 describes the relationship between the TOGAF ADM stages and the Zachman Framework's views [10].

Table 2. EVERY PERSPECTIVE SUITABILITY ZACHMAN FRAMEWORK WITH ADM TOGAF PHASE

\begin{tabular}{|c|c|c|}
\hline $\begin{array}{c}\text { Zachman Framework } \\
\text { Perspective }\end{array}$ & & TOGAF ADM stages \\
\hline \multirow[t]{5}{*}{ Planner } & 1 & Initial phase \\
\hline & 2 & Phase A (vision architecture), \\
\hline & 3 & Phase B (business architecture), \\
\hline & 4 & Phase C (information architecture), \\
\hline & 5 & Phase D (technology architecture) \\
\hline \multirow[t]{4}{*}{ Owner } & 1 & Initial phase \\
\hline & 2 & Phase A (vision architecture), \\
\hline & 3 & Phase B (business architecture), \\
\hline & 4 & Phase C (information architecture), \\
\hline \multirow[t]{4}{*}{ Designer } & 1 & Phase A (vision architecture), \\
\hline & 2 & Phase B (business architecture), \\
\hline & 3 & Phase C (information architecture), \\
\hline & 4 & Phase D (technology architecture) \\
\hline \multirow[t]{2}{*}{ Builder } & 1 & Phase C (information architecture), \\
\hline & 2 & Phase D (technology architecture) \\
\hline
\end{tabular}


The relationship between the phases in the TOGAF ADM with the current perspectives in the Zachman framework, namely:

\section{Planner}

In the initial phase, vision architecture, business architecture, information architecture, and technology architecture required a planner's perspective to determine enterprise business objectives at the start.

\section{Owner}

The Zachman Framework Model, related to product requirements, service needs, and business needs, is described from the owner's perspective. So that in TOGAF ADM, determining the needs from vision, business, data, and enterprise applications require the owner's point of view.

\section{Designer}

The phases of vision architecture, business architecture, information architecture, and technology architecture require a designer's perspective to model the business context and business processes in detail. In this perspective, a technical design model is described, which is the basis for implementing information systems to the required computer network infrastructure.

4. Builder

The information architecture and technology architecture phase requires a builder's perspective to build an overall information system and computer network infrastructure by enterprise requirements. Because from the builder's point of view, it is related to the development of information systems architecture and technology based on predetermined design models.

The TOGAF ADM phases used in this study are the vision phase, the business phase, the information phase, and the technology phase. In contrast, the Zachman framework perspective used is a Planner, Owner, and Designer.

\section{RESEARCH METHOD}

\section{A. Data Collection}

The data collection method was done qualitatively, namely, by conducting observations and interviews.

1. Observation is a process of observation to produce facts from human activities in a continuous and natural activity[11]. This method is done by coming directly to the research object to make observations and collect the necessary data related to the current academic system conditions. 
INTENSIF, Vol.5 No.1 February 2021

ISSN: 2580-409X (Print) / 2549-6824 (Online)

DOI: https://doi.org/10.29407/intensif.v5i1.14678

2. Focus Group Discussion (FGD) technique was used in interviews. According to Nyumba [12], The FGD technique aims to obtain respondents' perceptions of a theme by the research objectives. Interviews were conducted with related parties with the academic section of STMIK MPB and the leaders of STMIK MPB. This method is used to ensure that the data obtained is by the facts.

B. Characteristics of Respondents

Determination of respondents in this study using a purposive sampling method. According to Ayu Sri Mahatma Dewi[13], purposive sampling takes samples based on predetermined considerations. Respondents consisted of 2 academic staff, two information system management units, two heads of study programs, and two leaders. The data was collected using a question and answer polling process to the eight respondents who had been determined.

\section{RESULT AND DISCUSSION}

\section{A. Preliminary}

The preliminary phase is from the perspective of the Planner and Owner in the Zachman Framework. Based on Michael Porter's value chain concept, it provides a framework for identifying and inventorying functional areas. Based on the value chain concept[14], Academic business functions are divided into two, namely primary business functions and support business functions.

The main business functions in the academic section of STMIK-MPB are divided into three, namely (1) the admission process for new students, (2) academic operations, and (3) theoretical discharge or graduation. Meanwhile, the supporting business functions in the educational section of STMIK-MPB are (1) human resource management, (2) asset and infrastructure management, and (3) financial management. It can be seen in Figure 3.

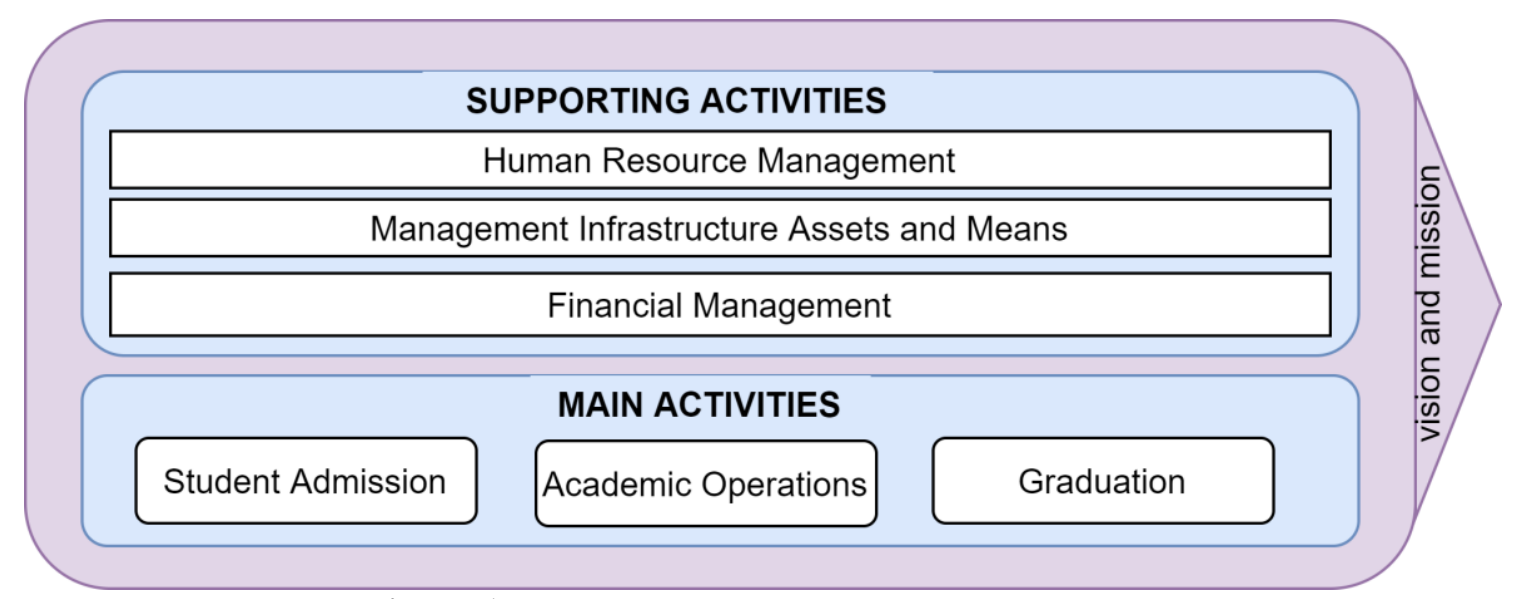

Figure 1. VAlue Chain Of ACADEMIC STMIK MPB 
Main activities consist of:

1. Student admission: student admission is a process of new student registration activities, unique student selection, and new student data collection.

2. Academic Operations: A process of academic administration management activities from being accepted as a student until the student graduates from college.

3. Graduation or discharge of students is an activity related to the process of academic end or academic release.

Supporting activities consist of:

1. Human Resource Management: is a process that supports activities to determine the needs of higher education operational human resources.

2. Asset and infrastructure management: is the process of managing infrastructure activities starting from planning, maintenance, and disposal.

3. Financial Management: This is a supporting activity related to budget planning related to the main activities and the maintenance of infrastructure facilities and infrastructure.

\section{B. Architecture Vision}

The Architecture Vision stages are found in the Planner, Owner, and Designer's perspective in the Zachman Framework. At this stage, Forming the same view on the importance of enterprise architecture to achieve the mission that has been determined, and determining the project scope boundaries, and determining the architectural model to be developed.

\section{Business Architecture}

The Business Architecture stages are found in the Planner, Owner, and Designer's perspective in the Zachman Framework. Bussines Architecture or business architecture determines the desired business model or business activity based on a business scenario (a business process that has been described in current conditions). Various techniques aim to model business architectures, such as Unified Modeling Language (UML) diagrams, Business Process Modeling Notation (BPMN), Integration Definition for Function Modeling (IDEF0), and Functional Decomposition Diagram (FDD)[15]. Figure 4 is a business process for conducting lectures; this business process is assisted by an information system based on the standard Business Process Modeling Notation (BPMN), a graphic notation that describes the steps in a business process. Business processes that are created should be evaluated to describe the current business process conditions and expected business processes. 
INTENSIF, Vol.5 No.1 February 2021

ISSN: 2580-409X (Print) / 2549-6824 (Online)

DOI: https://doi.org/10.29407/intensif.v5i1.14678

\section{Data Architecture}

Data Architecture identifies and defines the main data types that support predefined business functions. Data architecture planning takes the linkages and relationships between data entities to provide the basis for developing an enterprise architecture. Data entities need to be structured according to their relationship and relationship in the function area's context.

Table 3. CANDIDATES FOR ENTITY DATA ENTITIES

\begin{tabular}{cl}
\hline \hline No & \multicolumn{1}{c}{ Data Entity Candidates } \\
\hline 1 & Student Entities \\
\hline 2 & Lecturer Entity \\
\hline 3 & Lecturer Rating Entity \\
\hline 4 & Subject Entities \\
\hline 5 & Head of Study Program entity \\
\hline 6 & Lecture Hall entities \\
\hline 7 & Room Management Entities \\
\hline 8 & Infrastructure entity \\
\hline 9 & BAAK entity \\
\hline
\end{tabular}

One of the enterprise architecture stages is the data architecture in the information architecture, which is in the first column of the Zachman framework matrix and is part of the Information system Architecture phase in the TOGAF ADM phase. The first thing that must be done to define data architecture is to determine candidate data entities; entities are defined as places, concepts, people, objects, or events that have meaning (information) related to college academic business processes. Table 3 is an example of a candidate for lecture data entities.

After the candidate entity is defined, the entity is made a data architecture modeling described by the Entity-Relationship Diagram (ERD). According to Brady \& Loonam [16], ERD is a model created and consists of collecting necessary objects called entities and describing relationships between entities used in the system. ERD models data structures and relationships between data. Realized entities have cardinality and participation. Cardinality (or degree of relationship) is the number of entities involved in the relationship. 
INTENSIF, Vol.5 No.1 February 2021

ISSN: 2580-409X (Print) / 2549-6824 (Online)

DOI: https://doi.org/10.29407/intensif.v5i1.14678

Figure 4 is an example of an ERD lecture, and Figure 5 is an example of a business process for conducting studies.-

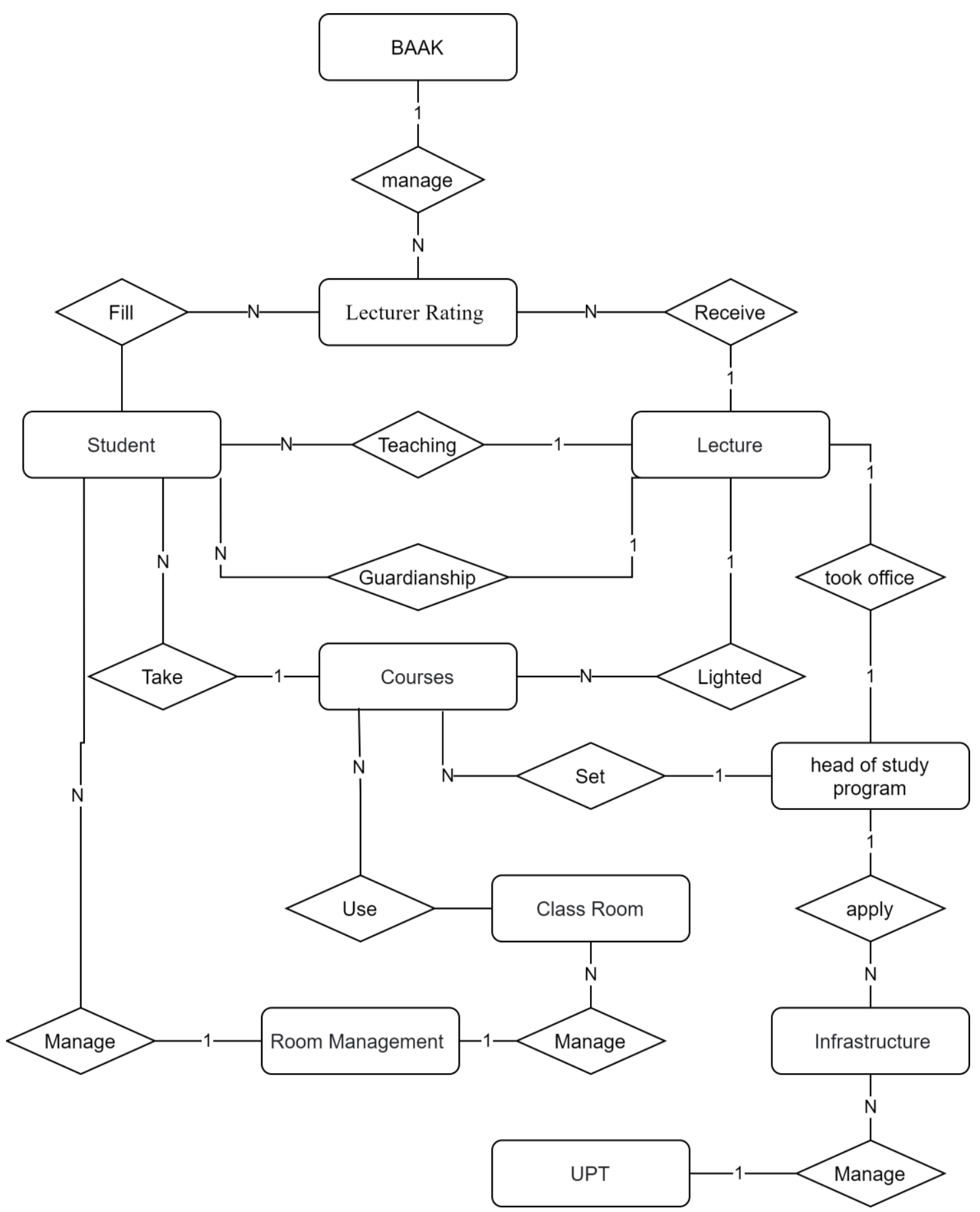

Figure 2. ER- DiAGRAM OF LECTURE 
INTENSIF, Vol.5 No.1 February 2021

ISSN: 2580-409X (Print) / 2549-6824 (Online)

DOI: https://doi.org/10.29407/intensif.v5i1.14678

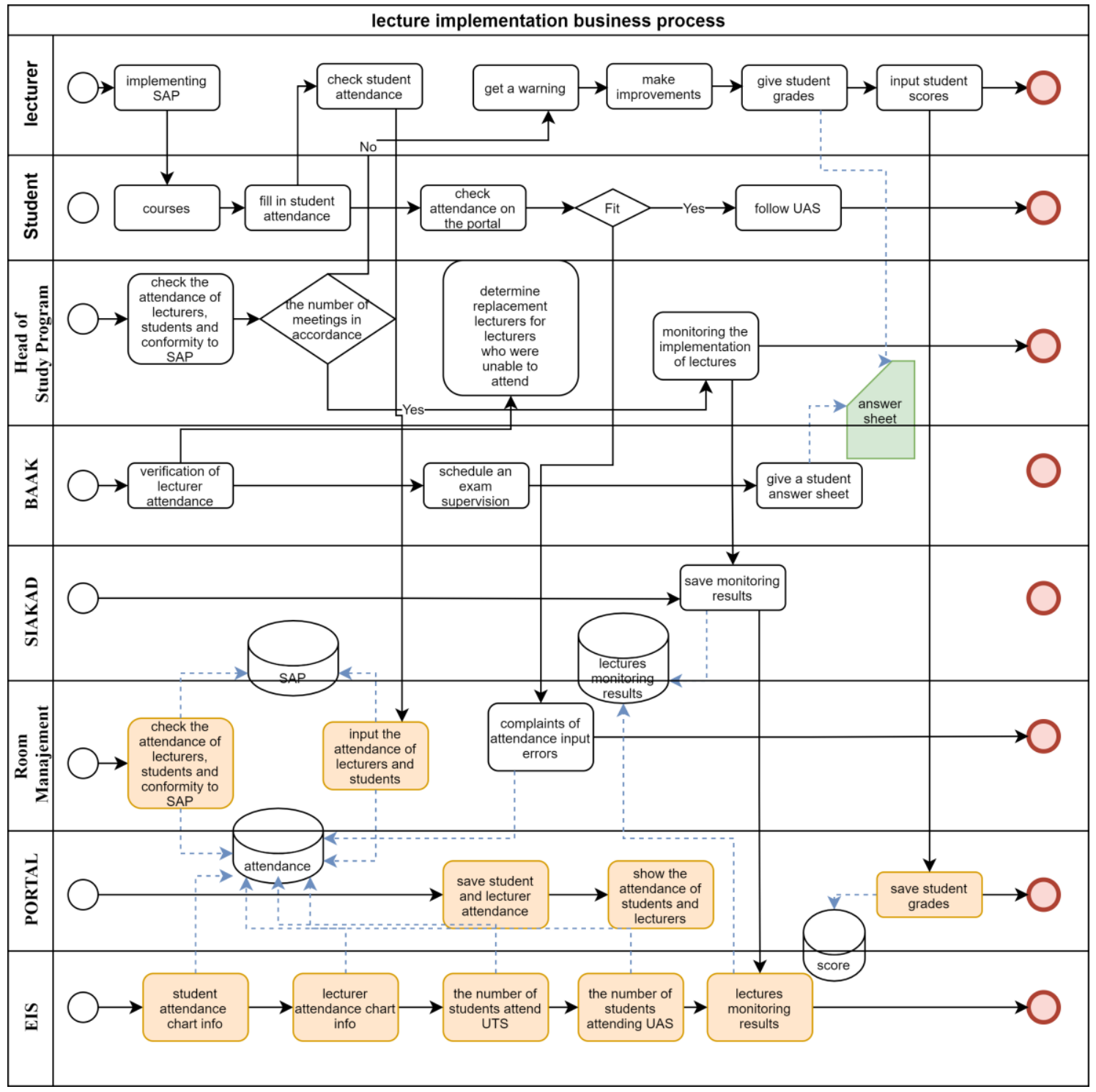

Figure 3. BUSINESS PROCESS OF IMPLEMENTING LECTURES

The next step is to create a process vs. data entity metric; the Entity Matrix links the business processes data. Each part of the "CUR" in the matrix has the meaning $\mathrm{C}$ (created), which means a function to determine the created data entities, $U$ (update), which means the part of updating and repairing, $\mathrm{R}$ (reference), which means the role can access data or use. The process that performs "C" implies "U" and "R." In contrast, the performing process "U" implies "R." This data architecture will show the data sharing by business functions. Then define the scope of future information systems and link applications to tasks that can create a sequence of application implementations. Table 4 is an example of process metrics vs. course data entities.

Table 4 shows their consistency in the grouping of business functions if you look at the areas arranged diagonally from the right to the bottom left. The shading distribution area on the matrix 
INTENSIF, Vol.5 No.1 February 2021

ISSN: 2580-409X (Print) / 2549-6824 (Online)

DOI: https://doi.org/10.29407/intensif.v5i1.14678

is an area or data with strong linkages with the business process or functional area. Besides, some of the information that is out of parts in shading is the data that is irregular due to the distribution process using data that are not clumped part relationship thick outside the box shows the level of data sharing on business.

Table 4. Process Metrics Vs LeCturing Data EnTities

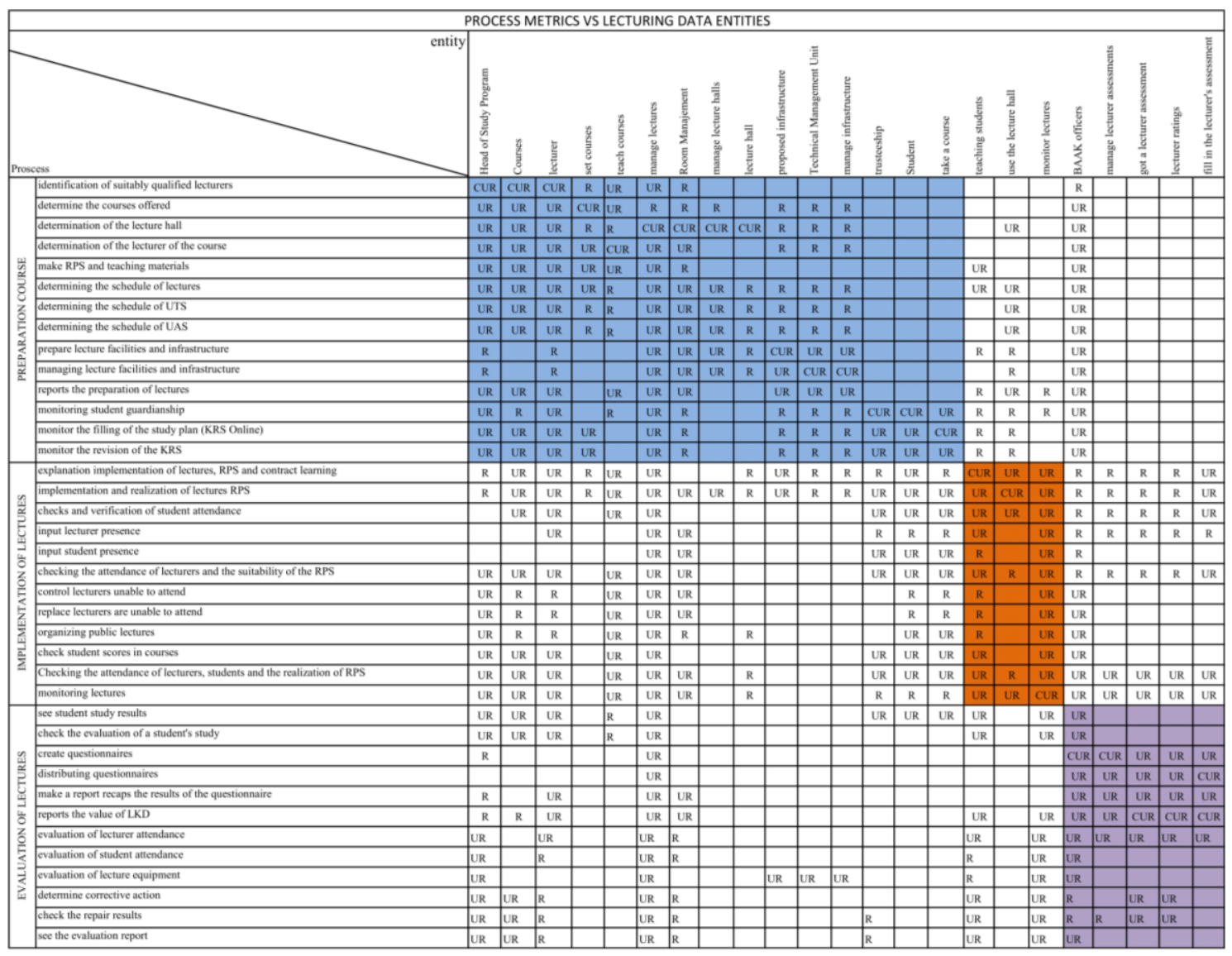

\section{E. Application Architecture}

Application Architecture or Application Architecture aims to define what applications are needed to manage data and support business functions. The application architecture stage is from the Planner, Owner, Designer, and builder's perspective, who is from the standpoint of the Zachman Framework. Application Portfolio Catalog techniques function to define application architecture; the purpose of the Application Portfolio Catalog is to represent all lists of applications used to manage existing business data and functions. Figure 6 is an example of an Application Portfolio Catalog. 
INTENSIF, Vol.5 No.1 February 2021

ISSN: 2580-409X (Print) / 2549-6824 (Online)

DOI: https://doi.org/10.29407/intensif.v5i1.14678

\begin{tabular}{|c|c|c|c|c|}
\hline \multicolumn{5}{|c|}{ MAIN ACTIVITIES } \\
\hline $\begin{array}{c}\text { New Student Admission } \\
\text { System }\end{array}$ & \multicolumn{3}{|c|}{ Academic Information System } & Academic Release System \\
\hline $\begin{array}{c}\text { marketing and promotion } \\
\text { system }\end{array}$ & re-registration system & lectures administration & attendance & $\left(\begin{array}{c}\text { the study dropout or study } \\
\text { drop system }\end{array}\right)$ \\
\hline $\begin{array}{c}\text { new student registration } \\
\text { system }\end{array}$ & academic leave system & KRS & curriculum & $\begin{array}{l}\text { resignation student } \\
\text { management system }\end{array}$ \\
\hline $\begin{array}{l}\text { registration payment } \\
\text { system }\end{array}$ & academic tutoring system & change of study plan & KHS & transcripts \\
\hline $\begin{array}{c}\text { admission exam } \\
\text { management system }\end{array}$ & $\begin{array}{c}\text { transfer student } \\
\text { administration system }\end{array}$ & scheduling lecture & academic reporting & Bachelor's Certificates \\
\hline admission exam system & academic calendar & exam scheduling & $\begin{array}{l}\text { final task management } \\
\text { system }\end{array}$ & graduation \\
\hline $\begin{array}{l}\text { student registration } \\
\text { system }\end{array}$ & scientific writing & score & & alumni \\
\hline $\begin{array}{l}\text { reporting system of } \\
\text { student admission }\end{array}$ & & & & reporting \\
\hline \multicolumn{5}{|c|}{ SUPPORTING ACTIVITIES } \\
\hline \multicolumn{2}{|c|}{ human resources management system } & $\begin{array}{l}\text { management system } \\
\text { infrastructure }\end{array}$ & \multicolumn{2}{|c|}{ financial management system } \\
\hline \multicolumn{2}{|c|}{ management SDM } & submission & \multicolumn{2}{|r|}{ budgets } \\
\hline \multicolumn{2}{|c|}{ leave application } & procurement & \multicolumn{2}{|c|}{ salaries of employees and lecturers } \\
\hline \multicolumn{2}{|c|}{ promotion } & inventory management & \multicolumn{2}{|c|}{ financial Accounting } \\
\hline \multicolumn{2}{|c|}{ training and education } & reporting & \multicolumn{2}{|c|}{ cost of education } \\
\hline \multicolumn{2}{|c|}{ payroll administration } & & \multicolumn{2}{|c|}{ reporting } \\
\hline \multicolumn{2}{|c|}{ reporting } & & & \\
\hline
\end{tabular}

Figure 4. APPLICATION PORTFOLIO CATALOG

Then the System/Function Matrix stage aims to connect applications with defined business functions. This stage seeks to identify business functions that are directly supported or performed by the application. With data orientation, cross-mapping between applications against data entities takes precedence. It can be done using a process vs data entity matrix. The grouping of matrix cells for application identification is applied by prioritizing cells that contain lots of "CUR", then with "UR" and "R" cells as the last priority. This priority is based on the essential applications that are used to support business processes in generating data. The sample results from the application vs. business function matrix are listed in Table 5 . 
INTENSIF, Vol.5 No.1 February 2021

ISSN: 2580-409X (Print) / 2549-6824 (Online)

DOI: https://doi.org/10.29407/intensif.v5i1.14678

Table 5. APPLICATION METRICS VS LECTURING BUSINESS PROCESSES

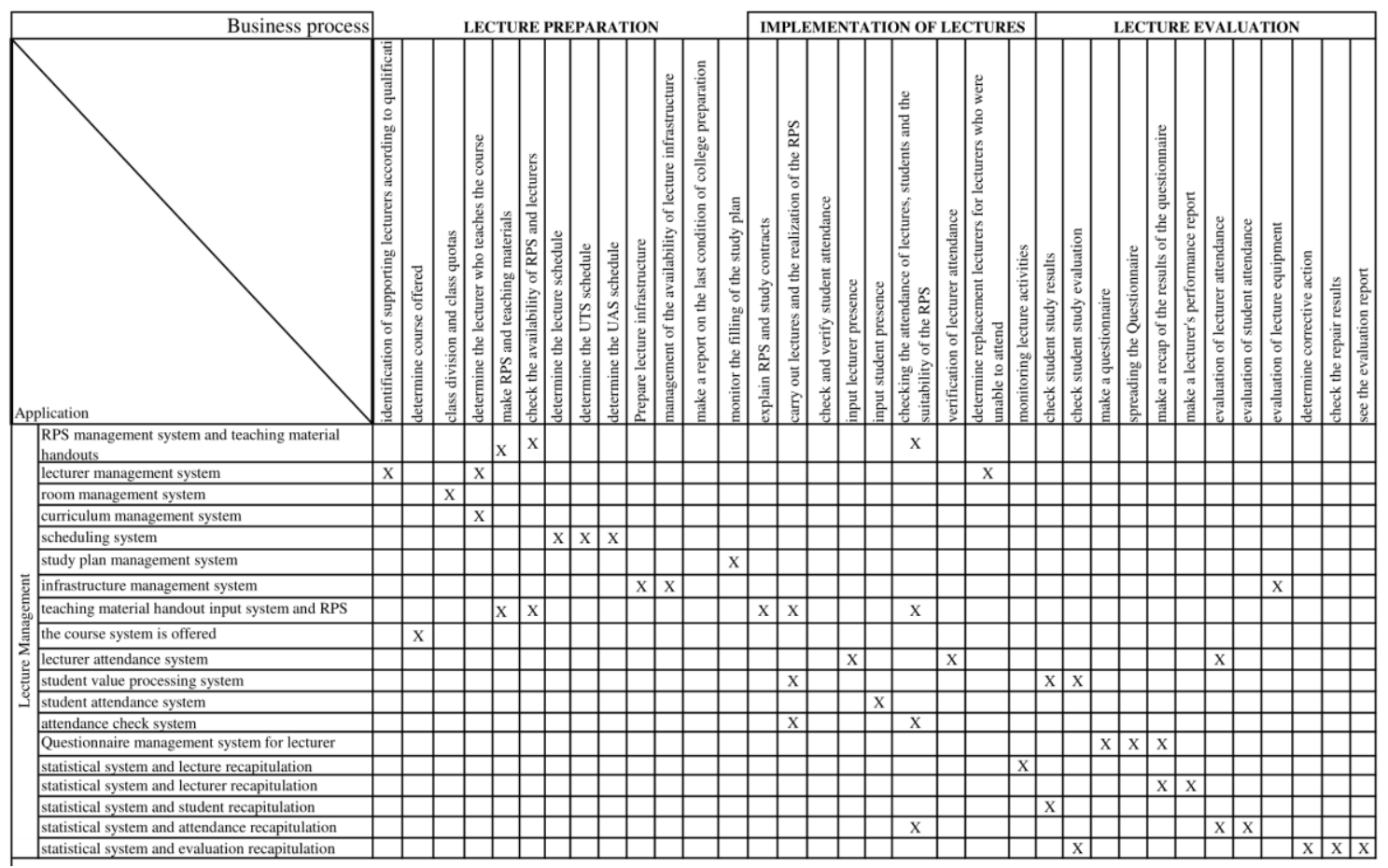

\section{F. Technology Architecture}

The development of technology architecture aims to define the technology requirements needed to process data. The first step is to determine the technology candidate to be used based on the technology catalog. In TOGAF ADM, a Technical Reference Model can classify the technology \{Formatting Citation . The result of technology classification is a clear and scalable technology selection for technology platforms, ranging from software, hardware, security, and communication technologies. Defining technology architecture aims to ensure that the technology is feasible, reasonable, and consistent with business and information architecture. Figure 7 shows the proposed network platform. 
INTENSIF, Vol.5 No.1 February 2021

ISSN: 2580-409X (Print) / 2549-6824 (Online)

DOI: https://doi.org/10.29407/intensif.v5i1.14678

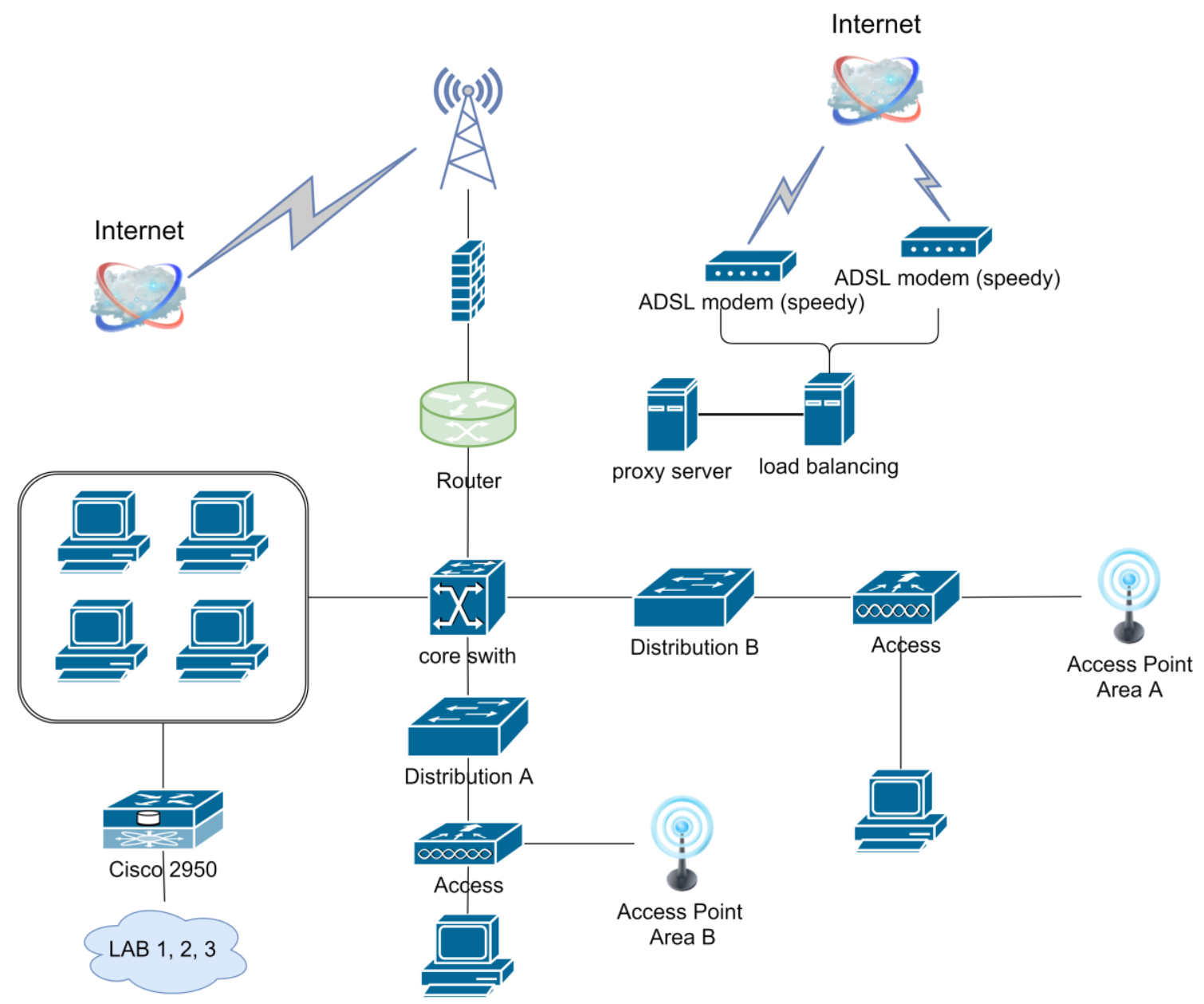

Figure 5. THE PROPOSED STMIK-MPB NETWORK

The resulting technology architecture is only conceptual. It cannot be used as a measure of needs but only provides an overview that needs to be reviewed when implemented.

\section{CONCLUSION}

The resulting Enterprise architecture results from integrating the Zachman framework and TOGAF ADM by paying attention to the relationship between each perspective in the Zachman Framework with the phases contained in TOGAF ADM. From the discussion, researchers can conclude that it can integrate the Zachman framework and TOGAF ADM from the viewpoint. The results of designing a model of combining the two architectures are expected to be used as a reference in developing information systems and technology in the academic section of STMIK MPB. 


\section{REFERENCES}

[1] A. Hakim, H. Saragih, And A. Suharto, "Jurnal Sistem Informasi ( Journal Of Information Systems ). Sist. Inf., Vol. 10, No. 2, Pp. 83-86, 2014.

[2] B. Azhar, F. Abdul, And R. Imam, "Enterprise Architecture Planning Sistem Informasi Akademik Dengan Togaf Adm," J-Sakti (Jurnal Sains Komput. dan Inform., Vol. 3, No. 1, P. 1, 2019.

[3] R. Supardi, "Pengembangan Model Arsitektur Enterprise Sistem Informasi Menggunakan Eap Pada Perguruan Tinggi (Studi Kasus di Universitas Dehasen Bengkulu)," J. Media Infotama, Vol. 12, No. 1, Pp. 70-78, 2016.

[4] S. Sunardi, I. Riadi, And P. A. Raharja, "Analisis Application Programming Interface Pada Mobile E-Voting Menggunakan Metode Test-Driven Development," Techno (Jurnal Fak. Tek. Univ. Muhammadiyah Purwokerto), Vol. 20, No. 2, P. 87, 2019.

[5] N. Safitri And R. Pramudita, "Pengembangan Kerangka Kerja Arsitektur Enterprise," Bina Insa. Ict J., Vol. 4, No. 1, Pp. 73-82, 2017.

[6] I. S. Wartika, "Analisis Perbandingan Komponen dan Karakteristik Enterprise Architecture Framework"Konferensi Nasional Sistem dan Informatika, Stikom Bali 2011.

[7] A. F. Husni, "Analisis Dan Pengembangan Sistem Informasi Akademik Dengan Permodelan Enterprise Architecture Zachman Framework Pada Politeknik Jambi," J. Inf. Politek. Indonusa Surakarta, Vol. 1, No. 3, Pp. 1-9, 2016.

[8] Ban-Pt, 2007, "Kumpulan Instrumen Standar 11 Sistem Informasi Institusi Perguruan Tinggi, Departemen Pendidikan Nasional.".

[9] O. Moscoso-Zea, S. Luján-Mora, C. E. Cáceres, and N. Schweimanns, "Knowledge Management Framework Using Enterprise Architecture And Business Intelligence," Inf. Syst., Vol. 1, No. Iceis, Pp. 244-249, 2016.

[10] R. Pramudita, And N. Safitri, "Integrasi Zachman Framework dan Togaf ADM ( Architecture Development Method ),” Inf. Syst. Educ. Prof., Vol. 1, No. 2, Pp. 157-166, 2016.

[11] H. Hasanah, “Teknik-Teknik Observasi,”Vol 8, No 1 Pp. 21-46.2016.

[12] T. O.Nyumba, K. Wilson, C. J. Derrick, And N. Mukherjee, "The Use Of Focus Group Discussion Methodology: Insights From Two Decades of Application In Conservation," Methods Ecol. Evol., Vol. 9, No. 1, Pp. 20-32, 2018.

[13] A. Sri, M. Dewi, And A. Wirajaya, "Pengaruh Struktur Modal, Profitabilitas dan Ukuran Perusahaan Pada Nilai Perusahaan," E-Jurnal Akunt., Vol. 4, No. 2, Pp. 358-372, 2013.

[14] K. Dilip And P. Rajeev, "Value Chain: A Conceptual Framework," Int. J. Inf. Eng. Manag. Sci., Vol. 7, No. 1, Pp. 74-77, 2016.

[15] T. O. Group, "Sample Catalogs, Matrices And Diagrams," Pp. 1-71, 2011.

[16] J. Brady, M., \& Poonam, Exploring The Use Of Entity-Relationship Diagramming As A Technique To Support Grounded Theory Inquiry. Bradford: Emerald Group. 2010.

[17] M. Lankhorst, Enterprise Architecture At Work - Enterprise Modeling, Communication, And Analysis - Second Edition, Vol. 36. 2013. 